\title{
Reprocessing Established Drugs For COVID-19
}

\author{
Siddhartha Pulukuri \\ Sharon High School, 181 Pond Street, Sharon, MA, 02067, USA; spulukuri2022@gmail.com
}

ABSTRACT: The newest type of virus, SARS-Cov2, in the family of coronaviruses has no effective treatments. Creating new drugs for specific viruses can take years and vaccines can take even longer. With such a large potential for destruction, it is of paramount importance that research leading to effective treatments is initiated. By repurposing previously known antiviral drugs and treatments, we can potentially treat COVID-19. Several drugs are already in clinical trials, in this review, we will be discussing remdesivir, hydroxychloroquine (HCQ), and nebulized alpha interferons.

KEYWORDS:Biomedical and Health Sciences; Genetics and Molecular Biology of Disease; COVID-19; Remdesivir; Interferons; Hydroxychloroquine.

\section{- Introduction}

In December of 2019, clusters of respiratory illnesses of unknown etiology broke out in the Wuhan district of the $\mathrm{Hu}-$ bei Province. This new illness was isolated and discovered by Chinese authorities to be a new form of Coronavirus (SARSCov2) on January 7 th, 2020. ${ }^{1}$ SARS-Cov2 causes COVID-19 which is a flu-like illness that is particularly fatal to the elderly. Before delving into treatment for the disease, it is important to examine SARS-Cov2.

\section{History of The Coronavirus:}

The Coronavirus is thought to have originated around as early as $2400 \mathrm{BC}$ as a zoonotic disease which was later identified in the 1950's. ${ }^{2}$ The Coronavirus family consists of the Alpha, Beta (Originating in Bats), Gamma, and Delta coronavirus (Originating in Birds). ${ }^{3}$ The virus responsible for SARS (Severe Acute Respiratory Syndrome) and MERS (Middle Eastern Respiratory Syndrome) are all examples of Beta coronaviruses. ${ }^{4}$ Throughout history, the coronavirus has had multiple spillover events, for example the SARS epidemic in 2002 and the MERS epidemic in 2012..$^{5}$

\section{Transmission of SARS-Cov2:}

Once a human is infected, SARS-Cov2 primarily spreads through respiratory droplets via coughing and sneezing. ${ }^{6}$ However, recent evidence suggests that salivary gland transmission, ocular discharge transmission, and fecal-oral transmission are also potential transmission methods. ${ }^{7}$ This is still an ever-evolving area of research as new studies are constantly confirming/disproving hypotheses.

\section{Viral Attachment and Entry:}

As seen in Figure 1, after making its way into the human body, the SARS-Cov2 initially binds its Spike (S) protein to the host proteins ACE2 and the serine protease, TMPRSS2. Following binding, the viral $\mathrm{S}$ protein is cleaved into two functional subunits, S1 which interacts with ACE2, and S2 that is further cleaved and activated by TMPRSS2. Together, these actions result in viral-host membrane fusion. ${ }^{8}$ These high-affinity interactions are essential in viral entry and are therefore prime targets in the treatment of COVID-19. For example, hydroxychloroquine (HCQ) has formerly been shown to inhibit the terminal glycosylation of ACE2 in malarial infections, and thus it was repurposed. Indeed, HCQ negatively influences the virus-receptor binding in SARS$\mathrm{CoV}$ infections. ${ }^{9}$ The beta-coronaviruses, SARS-CoV $1 / 2$ and MERS-CoV, have been shown to enter the host cell by endocytosis. ${ }^{10}$ During endocytosis, the virion is surrounded by the cell membrane and internalized via the formation of cytoplasmic vesicles termed endosomes. After entering the cell, the virus begins its replication cycle. ${ }^{11}$

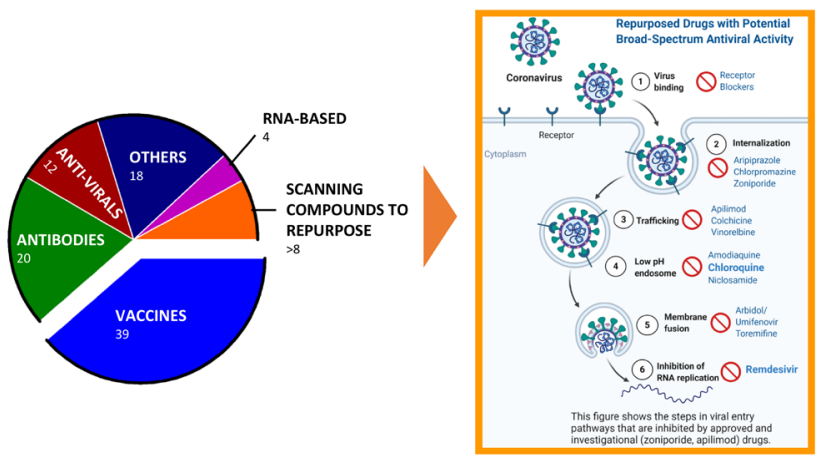

Figure 1: Snapshot of potential COVID-19 treatments and vaccines in research pipeline.

\section{Viral Replication:}

1. Virus Binding

After entry, the replication cycle that SARS-CoV-2 undergoes consists of five key steps: virus binding, internalization, trafficking, membrane fusion, and RNA replication. ${ }^{12,13} \mathrm{Vi}-$ ruses attach to the host cell by specific molecular interactions between proteins present on the surface of the cell, and proteins present on the surface of the virus.

2. Internalization 
After the virus has been bound, a variety of mechanisms occur directly through the plasma membrane or the membrane of the endosome following endocytic internalization of the virus particle. Ultimately, the end result is the entry of the viral capsid into the host cell's cytosol.

3. Trafficking

Nucleocytoplasmic trafficking of viral proteins is vital to viral infection. Virus trafficking in host cells depends upon a variety of host factors from cytoskeletal networks to endocytic machinery, which can all be targeted. Additionally, the fact that the virus requires an acidic environment inside the endosome for viral uncoating and nuclear translocation can also be targeted.

\section{Membrane Fusion}

During this process, the cell membrane is punctured in order to connect with the unfolding viral envelope. Once this occurs, the viral genome is injected into the host cell's cytoplasm.

\section{RNA Replication}

Because SARS-CoV-2 is an RNA virus, it must undergo RNA replication by a virus encoded RdRp. After all requirements for replication are ready, the virus begins to create copies itself in vast amounts.

\section{COVID-19 Symptoms in Humans:}

After the virus has replicated enough times to the point where the immune system sees a major threat, symptoms begin to appear in humans, which serves as a sign to show that the body is fighting the virus. The researchers of the Chinese Center for Disease Control divided the symptoms into three sections based on clinical manifestation: mild, severe, and critical disease. During the mild component, the symptoms are subdivided into uncomplicated illness and moderate pneumonia. Uncomplicated illness has symptoms similar to that of the flu such as mild fever, cough, nasal congestion, sore throat, malaise, headache, muscle aches, loss of taste/smell, diarrhea, and vomiting. After the disease has progressed into moderate pneumonia, tachypnea can be seen. Subsequently, severe disease means that severe pneumonia is present whose symptoms include fever associated with severe dyspnea, respiratory distress, hypoxia, and cyanosis appear. Once the disease manifests into critical disease, Acute Respiratory Distress Syndrome (ARDS), septic shock, and multiple organ dysfunction/failure can be observed. However, progression of the disease into the critical stage can be prevented through the use of antiviral drugs. ${ }^{14}$

\section{Discussion}

\section{Potential Repurposing Agents Against COVID-19:}

Antiviral drugs are designed to treat diseases such as COVID-19; however, creating drugs specifically for COVID-19 can take years due to the safety requirements and clinical trials necessary to prove its effectiveness and safety. In current situations where time is of the essence, it is best to utilize repurposed agents, or drugs that are effective against many kinds of viruses or diseases similar to COVID-19. As of right now, remdesivir, $\mathrm{HCQ}_{2}$ and nebulized alpha interferon treatment can all be utilized in the current outbreak, which requires urgent attention due to the vast number of growing cases. ${ }^{15}$

As seen in Figure 1, the majority of current research regarding COVID-19 is taking place in vaccine research, and repurposing compounds is one of the lowest priorities at this time. Although creating vaccines is important in the long run, it is important to note that vaccines will not help current patients that are suffering, and vaccine creation is also time-consuming. Thus, due to the value of time, it is important that the focus is shifted onto repurposing agents rather than vaccines. ${ }^{16}$ When deciding what compounds to use, it is important that how the drug targets the virus is observed. Our targets are determined by the viral replication cycle, of the five steps described above. ${ }^{17}$ Of these five steps, remdesivir targets RNA Replication, HCQ targets endosomal $\mathrm{pH}$ during trafficking, and interferons (IFNs) boost the immune response. $^{18-20}$

\section{Remdesivir: A Potential Repurposing Agent Against COVID-19:}

Remdesivir is an antiviral agent that was originally developed to treat the filoviruses Marburg and Ebola. ${ }^{21}$ As seen in Figure 2, the active molecule in remdesivir, GS-441524, inhibits viral RNA replication, thus leading to it being recognized as a broad-spectrum drug against RNA viruses. ${ }^{22}$ Remdesivir is an adenosine analog that blocks all nucleotides after adenosine, thus prematurely terminating RNA sequences. Intravenous administration of $10 \mathrm{mg} / \mathrm{kg}$ dose of remdesivir shows that it grants $100 \%$ protection against Ebola virus infection and the EC90 value is about $1.76 \mu \mathrm{M}$ in Vero E6 cells. ${ }^{18}$ Thus, remdesivir's potential against COVID-19 is promising.
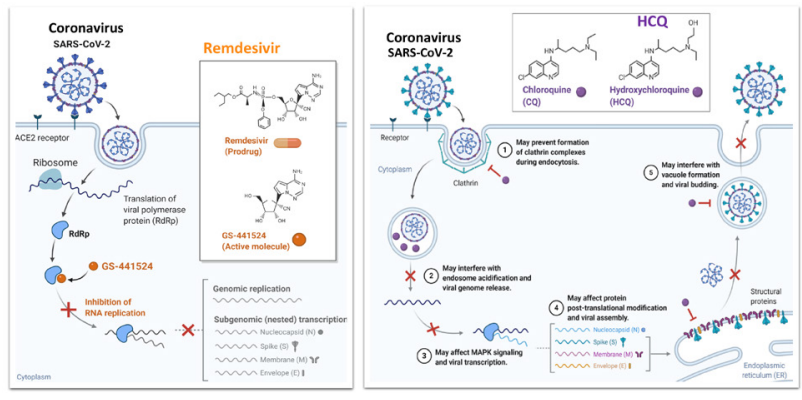

Figure 2: Remdesivir and Hydroxychloroquine: potential mechanisms of action against coronavirus.

As seen in Figure 3, remdesivir is being tested across a variety of countries' respective healthcare facilities. These trials could be crucial to finding an effective treatment for COVID-19, and few of these trials, such as Gileads and the National Institute of Health's (NIH), are occurring in the US itself. Gilead's Phase III clinical trial is an on-going randomized trial with roughly 6000 participants with Remdesivir as the standard of care with patients ranging from moderate to severe disease; the trial is split into 4 subcategories with different dosage periods ranging from 5 to 10 days and varying dosage amounts at either $100 \mathrm{mg}$ or $200 \mathrm{mg}$. The NIH clinical trial is a randomized placebo-controlled study with a double-blind, the trial has currently enrolled over 1000 participants. ${ }^{23}$ 


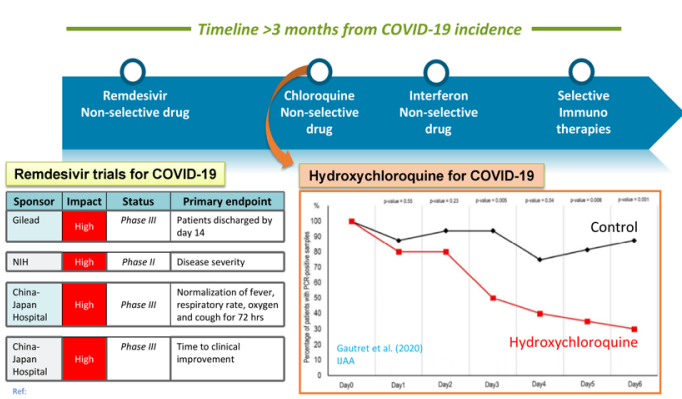

Figure 3: COVID-19 clinical trials.

\section{Hydroxychloroquine: A Potential Repurposing Agent Against CОИІD-19:}

$\mathrm{HCQ}$ is an anti-malarial and immunosuppressive drug with potential as a broad-spectrum antiviral drug. HCQ stands out from other drugs as it is effective at both entry and post-entry due to the nature of its inhibition. ${ }^{19}$ During endocytosis, capsules known as endosomes transport the virus, and in order for viral replication to ensue, it is required that the endosome be acidic. ${ }^{11}$ However, HCQ increases the $\mathrm{pH}$ of endosomes during viral entry, making the endosome inhospitable, and preventing viral RNA synthesis. As seen in Figure 2, these endosomes are present in both endocytosis and exocytosis, meaning HCQ functions at both points. ${ }^{24} \mathrm{On}$ top of this, hydroxychloroquine is inexpensive and has already been used in several patients with little to no adverse effects which highlight its treatment potential.

Additionally, looking at studies done on hydroxychloroquine, patients who took hydroxychloroquine as a medication began receiving significantly smaller amounts of positive PCR test results than the control group. As seen in Figure 3 , by day 6 , the percentage of positive samples went from 100 percent to roughly 30 percent, whereas the control group stayed around 90 to a 100 percent with smaller detectable amounts of virus particles. ${ }^{25}$ However, recent clinical trials have shown that Hydroxychloroquine has no significant impact on the clinical status of hospitalized adults. ${ }^{26}$

Alpha Interferons: A Potential Repurposing Agent Against COVID-19:

Pegylated (Pegylation is a type of chemical modification for therapeutic enhancement) interferon alfa- $2 a$ and alfa- $2 b$ have already been in use for treatment against HBV (Hepatitis B) and HCV (Hepatitis C). ${ }^{20}$ This type of treatment involves the induction of interferons (IFNs), which are proteins that are naturally released as warning mechanisms against infection. The advantage in utilizing IFNs is the fact that they respond to a broad spectrum of viruses and they work efficiently in all stages of viral replication. In essence, IFNs call immune cells such as Macrophages and Natural Killer (NK) cells to action, which ultimately contribute to fighting off the infection in the host. ${ }^{27}$

As seen in Figure 4, IFNs bind their receptor and lead to the activation of certain signaling pathways, mainly the JAK/STAT pathway. ${ }^{28}$ In normal cells, induction of STAT phosphorylation leads to interferon stimulated gene (ISG) expression and antiviral activity. However, in the case of a virus-infected cell, phosphorylation of STAT and ISG's is blocked, resulting in IFNs not being stimulated for use. ${ }^{29} \mathrm{Be}-$ cause of this, IFNs can't call the immune system to fight off the viruses, resulting in a lack of tools for the body's fight against the virus. In order to artificially stimulate these, IFNs will be administered intravenously or intramuscularly with varying dosages. These artificial IFNs will do the task of regular IFNs as if the virus-infected cell was healthy.
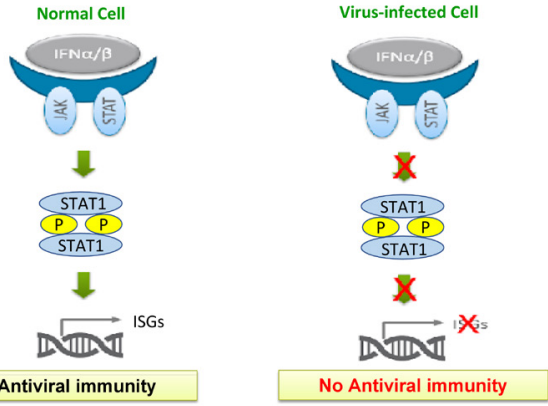

Figure 4: COVID-19 clinical trials.

Although these drugs and treatments are extremely effective, each of these has their own drawbacks. Remdesivir has proven to be effective in-vitro; however, in previous years it's success in-vitro and in-vivo have not translated to clinical trials. ${ }^{23}$ Hydroxychloroquine, on the other hand, can possibly cause diarrhea, muscle cramps, dizziness, headaches, nausea, or vomiting. ${ }^{30}$ Lastly, alpha interferon treatment is known to have several adverse effects such as anemia which need to be closely monitored. ${ }^{31}$ Despite these side effects, it is essential that we overlook the negative end of the spectrum as the benefits outweigh the disadvantages. Hydroxychloroquine is an extremely cheap drug that is relatively common and Remdesivir has a relatively safe track record; however, in recent trials, hydroxychloroquine has been linked to arrhythmias and participants of the trial were twice as susceptible to heart attacks. ${ }^{32}$ Alpha Interferon treatment can also be safe if dosages are closely monitored and intervention is ready if necessary. Overall, these side effects can be overcome with careful planning and monitoring, and hydroxychloroquine can be monitored closely to ensure that serious side effects don't appear.

\section{- Conclusion}

Remdesivir, hydroxychloroquine, and alpha interferons are individually very effective; however, in order to account for the vast heterogeneity in patients, it would be best to use a cocktail of these drugs in carefully controlled dosages to due to the fact that it could effectively neutralize virus particles inside a patient in any stage of infection. Due to the individual strengths of each drug, the cocktail could be administered to a wide variety of patients with varying levels of exposure and symptoms.

In addition to these three drugs, researchers are also looking into a corticosteroid called Dexamethasone and an anti-rheumatic drug called Tocilizumab. After COVID-19 progresses, diffuse lung damage can occur, but Dexamethasone modulates inflammation-mediated lung injury, resulting in a higher survival rate for patients and decreasing the risk of further progression into respiratory failure. ${ }^{33}$ Additionally, the body will sometimes release a cytokine storm as a last-ditch attempt to subdue COVID-19, however this storm damages the body as 
well as the virus. In order to mitigate the side effects, which can include lung tissue fibrosis, Tocilizumab is used. ${ }^{34}$ It is clear that these are all very viable drugs, however they primarily focus on alleviating symptoms of COVID-19 rather than directly affecting the viruses in the host, which makes remdesivir, hydroxychloroquine, and interferons a better approach.

Although there are a good number of trials regarding COVID-19 treatment, a majority of the trials are focusing on vaccines. Rather than focusing on long-term issues, we should first prioritize repurposing drugs for COVID-19 treatment. If we take the time to look into the medicine of our past and see how it can be used now, we could accomplish our goal of creating a gold-standard treatment for COVID-19. Ideally, these trials wouldn't just test a single drug against COVID-19, but rather a cocktail of drugs designed to inhibit the virus at several stages of disease. In a randomized placebo-controlled trial, this cocktail would be delivered at an effective dose and monitored for any adverse effects. These adverse effects would not only include side effects from each individual drug, but also any interactions between the drugs that could potentially be deadly. The most beneficial aspect in my opinion is the fact that SARS-CoV-2 will not have as great of a chance of mutating in order to gain immunity from a drug as it would have had if only one drug was consistently used to treat it. This protection from developing immunity would be very important as it means there's a lower chance of SARS-CoV-2 coming back annually.

As Benjamin Franklin stated, "Lost time is never found again", and therefore it is important to safely find a treatment for COVID-19 as soon as possible. Repurposing drugs gives a chance to effectively use the time given, and efficiently using this time is of paramount importance in a pandemic.

\section{Acknowledgements}

I would like to take the time to acknowledge primarily my family who has supported me in all my scientific endeavors, and also Dr. Ajit Bharti for allowing me to kindle my passion for science in his labs and teaching me the skills to approach problems scientifically.

\section{References}

1. Mackenzie JS, Smith DW. "COVID-19: A Novel Zoonotic

Disease caused by a Coronavirus from China: what we know and what we don't." Microbiol Aust., MA20013 (2020): doi:10.1071/ MA20013.

2. Woo PC, Lau SK, Lam CS, Lau CC, Tsang AK, Lau JH, Bai R, Teng JL, Tsang CC, Wang M, Zheng BJ, Chan KH, Yuen KY. "Discovery of Seven Novel Mammalian and Avian Coronaviruses in the Genus Deltacoronavirus supports Bat Coronaviruses as the Gene Source of Alphacoronavirus and Betacoronavirus and Avian Coronaviruses as the Gene Source of Gammacoronavirus and Deltacoronavirus.”J Virol. (2012), 86(7):3995-4008. doi: 10.1128/ JVI.06540-11.

3. Cui J, Li F, Shi ZL. "Origin and Evolution of Pathogenic Coronaviruses.” Nat Rev Microbiol. (2019), 17(3):181-192. doi: 10.1038/s41579-018-0118-9.

4. Petrosillo N, Viceconte G, Ergonul O, Ippolito G, Petersen E. "COVID-19, SARS and MERS: are they closely related?." Clin Microbiol Infect. (2020), 26(6):729-734. doi: 10.1016/j. cmi.2020.03.026.
5. Cascella M, Rajnik M, Cuomo A, Dulebohn SC, Di Napoli R. "Features, Evaluation and Treatment Coronavirus (COVID-19)." In: StatPearls [Internet]. Treasure Island (FL): StatPearls Publishing; 2020. PMID: 32150360.

6. Ye ZW, Yuan S, Yuen KS, Fung SY, Chan CP, Jin DY. "Zoonotic Origins of Human Coronaviruses.” Int J Biol Sci. (2020), 16(10):1686-1697. doi:10.7150/ijbs.45472.

7. Gu J, Han B, Wang J. “COVID-19: Gastrointestinal Manifestations and Potential Fecal-Oral Transmission.” Gastroenterology (2020), 158(6):1518-1519. doi: 10.1053/j.gastro.2020.02.054.

8. Belouzard S, Millet JK, Licitra BN, Whittaker GR. "Mechanisms of Coronavirus Cell Entry Mediated by the Viral Spike Protein." Viruses (2012), 4(6):1011-1033. doi:10.3390/v4061011.

9. Vincent MJ, Bergeron E, Benjannet S, Erickson BR, Rollin PE, Ksiazek TG, Seidah NG, Nichol ST. "Chloroquine is a Potent Inhibitor of SARS Coronavirus Infection and Spread.” Virol J. (2005), 2:69. doi: 10.1186/1743-422X-2-69.

10. Burkard C, Verheije MH, Wicht O, Kasteren SI, Kuppeveld FJ, Haagmans BL, Pelkmans L, Rottier PJM, Bosch BJ, Haan CAM. "Coronavirus Cell Entry occurs through the Endo-/Lysosomal Pathway in a Proteolysis-dependent manner." PLoS pathogens (2014), 10(11):e1004502. doi:10.1371/journal.ppat.1004502.

11. Cossart P, Helenius A. "Endocytosis of Viruses and Bacteria." Cold Spring Harb Perspect Biol. (2014), 6(8):a016972. doi: 10.1101/cshperspect.a016972.

12. Hillen HS, Kokic G, Farnung L, Dienemann C, Tegunov D, Cramer P. "Structure of Replicating SARS-CoV-2 Polymerase." Nature (2020), 584(7819):154-156. doi:10.1038/s41586-0202368-8.

13. Fehr AR, Perlman S. "Coronaviruses: an overview of their Replication and Pathogenesis." Methods Mol Biol. (2015), 1282:123. doi: 10.1007/978-1-4939-2438-7_1.

14. Cascella M, Rajnik M, Cuomo A, Dulebohn SC, Di Napoli R. "Features, Evaluation and Treatment Coronavirus (COVID-19)." In: StatPearls [Internet]. Treasure Island (FL): StatPearls Publishing; 2020. PMID: 32150360.

15. Tuli S, Tuli S, Tuli R, Gill SS. "Predicting the Growth and Trend of COVID-19 Pandemic Using Machine Learning and Cloud Computing." Internet of Things (2020), 11:100222. doi:10.1016/j. iot.2020.100222.

16. Alexander SPH, Armstrong JF, Davenport AP, Davies JA, Faccenda E, Harding SD, Levi-Schaffer F, Maguire JJ, Pawson AJ, Southan C, Spedding M. "A Rational Roadmap for SARS-CoV-2/ COVID-19 Pharmacotherapeutic Research and Development."Br J Pharmacol. (2020), 10.1111/bph.15094. doi:10.1111/bph.15094.

17. Magden J, Kaariainen L, Ahola T. "Inhibitors of Virus Replication: recent developments and prospects.” Appl Microbiol Biotechnol. (2005), 66(6):612-21. doi: 10.1007/s00253-004-1783-3.

18. Wang M, Cao R, Zhang L, Yang X, Liu J, Xu M, Shi Z, Hu Z, Zhong W, Xiao G. "Remdesivir and Chloroquine Effectively Inhibit the recently emerged Novel Coronavirus $(2019-\mathrm{nCoV})$ in vitro." Cell Res. (2020), 30(3):269-271. doi: 10.1038/s41422-0200282-0.

19.Singh AK, Singh A, Shaikh A, Singh R, Misra A. "Chloroquine and hydroxychloroquine in the treatment of COVID-19 with or without diabetes: A Systematic Search and a Narrative Review with a Special Reference to India and other Developing Countries." Diabetes Metab Syndr. ～(2020), 14(3):241-246. doi: 10.1016/j. dsx.2020.03.011.

20. Liu C, Chuang W, Lee C, Yu M, Lu S, Wu S, Liao L, Chen C, Kuo H, Chao Y, Tung S, Yang S, Kao J, Liu C, Su W, Lin C, Jeng Y, Chen P, Liu D. "Peginterferon Alfa-2a plus Ribavirin for the Treatment of Dual Chronic Infection with Hepatitis B and 
C Viruses." Gastroenterology (2009), 136(2):496-504.e3. doi:10.1053/j.gastro.2008.10.049.

21. Warren TK, Jordan R, Lo MK, Ray AS, Mackman RL, Soloveva V, Siegel D, Perron M, Bannister R, Hui HC, Larson N, StrickleyR, Wells J, Stuthman KS, Van Tongeren SA, Garza NL, Donnelly G, Shurtleff AC, Retterer CJ, Gharaibeh D, Zamani R, Kenny T, Eaton BP, Grimes E, Welch LS, Gomba L, Wilhelmsen CL, Nichols DK, Nuss JE, Nagle ER, Kugelman JR, Palacios G, Doerffler E, Neville S, Carra E, Clarke MO, Zhang L, Lew W, Ross B, Wang Q, Chun K, Wolfe Babusis D, Park Y, Stray KM, Trancheva I, Feng JY, Barauskas O, Xu Y, Wong P, Braun MR, Flint M, McMullan LK, Chen SS, Fearns R, Swaminathan S, Mayers DL, Spiropoulou CF, Lee WA, Nichol ST, Cihlar T, Bavari S. "Therapeutic Efficacy of the Small Molecule GS-5734 against Ebola virus in rhesus monkeys." Nature (2016), 531(7594):381-5. doi: 10.1038/nature17180.

22. Wu C, Liu Y, Yang Y, Zhang P, Zhong W, Wang Y, Wang Q. Xu Y, Li M, Li X, Zheng M, Chen L, Li H. "Analysis of Therapeutic Targets for SARS-CoV-2 and Discovery of Potential Drugs by Computational Methods." Acta Pharm Sin B. (2020), 10(5):766-788. doi: 10.1016/j.apsb.2020.02.008.

23. Eastman RT, Roth JS, Brimacombe KR, Simeonov A, Shen M, Patnaik S, Hall MD. "Remdesivir: A Review of Its Discovery and Development Leading to Emergency Use Authorization for Treatment of COVID-19.” ACS Cent Sci. (2020), 6(5):672-683. doi: 10.1021/acscentsci.0c00489.

24. Al-Bari, MAA. "Targeting Endosomal Acidification by Chloroquine Analogs as a Promising Strategy for the Treatment of Emerging Viral Diseases." Pharmacol Res Perspect. (2017), 5(1):e00293. doi: 10.1002/prp2.293.

25. Gautret P, Lagier J, Parola P, Hoang VT, Meddeb L, Mailhe M, Doudier B, Courjon J, Giordanengo V, Vieira VE, Dupont HT, Honore S, Colson P, Chabriere E, Scola BL, Rolain J, Brouqui $\mathrm{P}$, Raoult D. "Hydroxychloroquine and Azithromycin as a Treatment of COVID-19: results of an Open-label Nonrandomized Clinical Trial.” Int J Antimicrob Agents (2020), 56(1):105949. doi:10.1016/j.ijantimicag.2020.105949.

26.Self WH, Semler MW, Leither LM, et al. "Effect of Hydroxychloroquine on Clinical Status at 14 Days in Hospitalized Patients With COVID-19."JAMA Network(2020),324(21):21652176. doi: 10.1001/jama.2020.22240.

27. Perry AK, Chen G, Zheng D, Tang H, Cheng G. "The Host Type I Interferon Response to Viral and Bacterial Infections." Cell Res. (2005), 15(6):407-22. doi: 10.1038/sj.cr.7290309.

28. Nan Y, Wu C, Zhang YJ. "Interplay between Janus Kinase/Signal Transducer and Activator of Transcription Signaling Activated by Type I Interferons.

29.Crosse KM, Monson EA, Beard MR, Helbig KJ. "InterferonStimulated Genes as Enhancers of Antiviral Innate Immune Signaling." J Innate Immun. (2018), 10(2):85-93. doi: $10.1159 / 000484258$

30.Stokkermans T, Goyal A, Bansal P, Trichonas G. "Chloroquine And Hydroxychloroquine Toxicity.” In: StatPearls [Internet]. Treasure Island (FL): StatPearls Publishing; 2020.

31. Sleijfer S, Bannink M, Van Gool AR, Kruit WH, Stoter G. "Side Effects of Interferon-alpha Therapy.” Pharm World Sci. (2005), 27(6):423-31. doi: 10.1007/s11096-005-1319-7.

32. Owens B. "Hydroxychloroquine Side-effects Raise Concerns for Rheumatology Patients." Lancet Rheumatol. (2020), e390. S26659913(20)30184-3. doi: 10.1016/S2665-9913(20)30184-3.

33. Horby P, Lim WS, Emberson JR, Mafham M, Bell JL, Linsell L, Staplin N, Brightling C, Ustianowski A, Elmahi E, Prudon B, Green C, Felton T, Chadwick D, Rege K, Fegan C, Chappell LC,
Faust SN, Jaki T, Jeffery K, Montgomery A, Rowan K, Juszczak E, Baillie JK, Haynes R, Landray MJ. "Dexamethasone in Hospitalized Patients with Covid-19 - Preliminary Report.” N Engl J Med. (2020), NEJMoa2021436. doi: 10.1056/ NEJMoa2021436.

34.Guaraldi G, Meschiari M, Cozzi-Lepri A, Milic J, Tonelli R, Menozzi M, Franceschini E, Cuomo G, Orlando G, Borghi V, Santoro A, Di Gaetano M, Puzzolante C, Carli F, Bedini A,Corradi L, Fantini R, Castaniere I, Tabbì L, Girardis M, Tedeschi Giannella M, Bartoletti M, Pascale R, Dolci G, Brugioni L, Pietrangelo A, Cossarizza A, Pea F, Clini E, Salvarani C, Massari M, Viale PL, Mussini C. "Tocilizumab in Patients with Severe COVID-19: a Retrospective Cohort Study." Lancet Rheumatol. (2020), 2(8):e474-e484. doi: 10.1016/S2665-9913(20)30173-9.

\section{- Author}

Siddhartha Pulukuri is a Junior at Sharon High School who has dedicated his time to researching breast cancer at Boston University School of Medicine since freshman year of high school. He hopes to major in either immunology or microbiology and one day become a clinical virologist. 